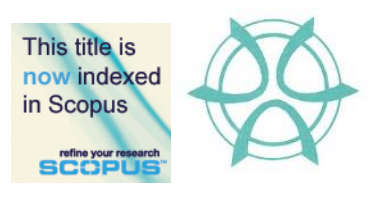

PLANNING MALAYSIA:

Journal of the Malaysian Institute of Planners

VOLUME 16 ISSUE 2 (2018), Page 141 - 152

\title{
GEN Z'S ACTIVITIES AND NEEDS FOR URBAN RECREATIONAL PARKS
}

\author{
Nurfaezah Ghani ${ }^{1}$, Mazlina Mansor ${ }^{2}$ \& Khalilah Zakariya ${ }^{3}$ \\ 1,2,3 Kulliyyah of Architecture and Environmental Design \\ INTERNATIONAL ISLAMIC UNIVERSITY MALAYSIA
}

\begin{abstract}
A public recreational park for youth is important in promoting leisure activities for their health. Engagement with outdoor activity contributes to healthy growth development physically, mentally and socially. Youth prefers places that offer favourable facilities where they can express themselves with presence friends. The study focuses on Generation Z youth (Gen Z), who are born between the mid of the 1990s through the late 2000s. The study investigates Gen Z activities and needs of recreational parks in Kuala Lumpur. The study obtained 564 respondents who lived in five strategic zones in Kuala Lumpur. Their responses were statistically analyzed using the SPSS. Results showed that the Gen Z frequented recreational parks near their homes. Titiwangsa Lake Garden, KLCC Park and Kepong Metropolitan Park are among their place preference. A recreational park for them should have more natural attributes and meet their active lifestyle. The places encourage them to have an active engagement and positive socialization with others.
\end{abstract}

Keywords: public recreational parks, generation Z, youth, activities, needs 
Nurfaezah Ghani, Mazlina Mansor \& Khalilah Zakariya

Gen Z's Activities and Needs for Urban Recreational Parks

\section{INTRODUCTION}

Youths in Malaysia are an important asset of the future because they have the potential to achieve success in various aspects. Currently, a majority of early youths in Malaysia is among the generation $\mathrm{Z}$ (Gen Z). They were born between 1995 to 2001 . The lifestyle and health of Gen $Z$ need to be addressed in order to produce proactive youths, equipped with skills, talent and creativity. Leisure activities among youths are diverse and they play an important role in forming of their self-perceptions. Hence, youths need access to the outdoor environment to support their healthy development (Latifiyan \& Salayati, 2015). Urban recreational park is an alternative place, other than city center (shopping mall, school and home environment) to promote outdoor leisure activities among Gen $\mathrm{Z}$ youths. It is a place that they can gather with friends, be alone, and learn.

Nonetheless, there is still a lack of recreational areas in Kuala Lumpur for Gen $\mathrm{Z}$ youth. Design of recreational park gives more priority to users such as family group and children as compared to youths' needs (Makinen \& Tyrvainen, 2008). Gen $Z$ needs space that they can enjoy and have fun doing their favourite activities. The lack of appropriate space of leisure is feared to contribute to unhealthy activities and social problems among youths. Design attributes for youths' recreational area include location of parks, facilities and maintenance aspects need to be improved in order to encourage them to have an active engagement with the outdoor environment.

The study aim to determine the criteria of space by identifying the relationship between the leisure time activities and the needs of Gen $Z$ youth. The paper presents findings that explore the use of parks' in Kuala Lumpur by Gen Z, and the types of activities needed of public recreational parks. The study is important to reveal needs and factors that can make recreational parks more attractive to fulfil this generation's needs.

\section{LITERATURE REVIEW}

A generation is a group of people born in the same era, shaped by the same time and influenced by the same social markers. Generation $\mathrm{Z}$ is today's children, teenagers and youths. They are the first generation of the 21st century and was born from the mid of the 1990s to the late 2000s (Sladek \& Grahinger, 2014). Gen $\mathrm{Z}$ is also known as digital natives, iGen, Post-Millennials, Centennials, or Plurals. Their behavior is said to be quite different from previous generations. They are characterized as 'Digital Natives', as they are always following the development of information and communications technology (ICT). They have inclination to learn new things in many ways based on their needs (McCrindle \& Wolfinger, 2008; Rabe et.al 92017) A statistic in Malaysia projected that the population of Gen $\mathrm{Z}$ will increase from nearly 3 million in 2016 to 5.5 million in 2020 (Department of Statistic Malaysia, 2016). Gen Z's world in terms of lifestyle and inspiration are largely shaped by the internet and the technology. 
PLANNING MALAYSIA

Journal of the Malaysia Institute of Planners (2018)

They spend an average of 7.5 hours using media and looking at the screen (Rideout, Foehr, \& Roberts, 2010). As such, there is a tendency that they prefer sedentary pursuits rather than sport activities, or actively participating in games at leisure time (Poh, Safiah, Tahir, Siti Haslinda, \& Siti Norazlin 2010; Wilson, 2006). It is claimed that their participation in sports or physical activities is low (Lim et al., 2016). For example, a study found that only $22 \%$ of Malaysian teenagers (15-18 years old) participate in regular sport or physical activity (at least 4200 minutes per week) (Aminuddin et. al., 2009). It was confirmed that those who prefer to stay indoor during leisure time afflict themselves to sedentary behaviour (Biddle, Marshall, Gorely, \& Cameron, 2009). A sedentary behavior often begins at childhood and adolescence stages. Without intervention, the behavior will continue into adulthood, resulting in many chronic diseases. Regular physical activity, recreational activities and healthy eating habits are the mitigation steps for Gen $\mathrm{Z}$ to prevent the chronic diseases in their adult life.

Research has shown that youths' outdoor leisure activities give positive effects towards their health, growth development and attitudes (Rabe et al., 2017). A recreational park is an ideal place for Gen $\mathrm{Z}$ to be active due to its natural attributes and facilities. It is suggested that the majority of users in recreational park is among youth generation (Rabe et al., 2017). Leisure activities in public recreational parks are preferred because it is accessible without any entrance fee. It is suggested that a high frequency of recreational park usage by youths is an indicator that the design features of the park is successful. It means that preference of youths for a recreational park is influenced by the criteria of the parks (Ngesan, Karim, Zubir, \& Ahmad, 2013; Abd-Latif, Nor, \& Omar-Fauzee, 2011). For example, the youths are more concerned about the condition of equipment and the natural views because these criteria influence their mood and feelings to play and enjoy activities (Kahiruddin, Mohd Yunos, Mydin, \& Ujang, 2015). Distance of play area with their residential areas also influence their choice to frequent a park (Danis, Sidek, \& Yusof, 2014; Zulkia, Zainol, Zainol, \& Nordin, 2014). Typical types of recreational park facilities, compatible with the youths comprise of baseball fields, basketball courts, picnic areas, open lawns, jogging tracks and many more. Youths' demands on the types of facilities change over time (Rabe et al, 2017). Currently trending activities that magnetize the youths are skateboarding, roller skating, rock climbing and bike riding (Kahiruddin et al., 2015). Hence, a park with specific themes such as skatepark, outdoor wall climbing, Parkour Park and street art park are some of the examples of play spaces anticipated by Gen $\mathrm{Z}$ youths.

On the other hand, there are various issues relating to recreational parks usage and some are associated with youths' unhealthy social activities. Reported cases include loitering, illegal racing, vandalism and graffiti. One of the main factors that contribute to the social issues are lack of appropriate open spaces compatible to youth's needs (Kahiruddin et al., 2015). The issues relate to the 
Nurfaezah Ghani, Mazlina Mansor \& Khalilah Zakariya

Gen Z's Activities and Needs for Urban Recreational Parks

provision of recreational parks and conducive parks' designs for youths' activities.

\section{MATERIALS AND METHOD}

\section{Unit of Analysis}

The respondents consist of Gen $\mathrm{Z}$ youth who live in Kuala Lumpur. The total population of Gen Z in Kuala Lumpur is 115, 600 (Department of Statistic Malaysia, 2016), and based on this number, the minimum sample size required for this study is 383 . The survey obtained a total of 564 respondents within the age of 15 to 21 years old. The sample size is considered sufficient.

\section{Research Instrument}

A self-administered survey questionnaire serves as the primary data for this research. The survey covers parameters that include leisure time needs of Gen Z and their activities in the recreational park. The questionnaire was designed with a combination of open-ended and closed-ended questions. The questions consist of dichotomous scale, categorical scale and a positive five-point Likert format (response from 5-strongly agree with 1-strongly disagree and a 3-neutral option). The questionnaire form consists of five sections including respondents' demographic profile, leisure time activities, outdoor public spaces, activities in recreation parks and health status. The survey items were derived from the dimensions established by a literature research especially the articles from 2008 until the current ones because the first generation of Gen $\mathrm{Z}$ youth emerged in 2008 at the age of 15 .

\section{Methods of Data Collection}

The sampling method was convenient sampling, which was carried out in two ways. First, the researchers distributed the survey forms to the passers-by in the recreational park. Self-administered questionnaire surveys were conducted at several recreational parks located in six strategic zones of Kuala Lumpur city. They are the areas of Kuala Lumpur City Center (zone A), Wangsa Maju-Maluri (zone B), Sentul-Manjalara (zone C), Damansara-Penchala (zone D), Bukit JalilSeputeh (zone E) and Bandar Tun Razak-Sungai Besi (zone F). 13 recreational parks were selected as these parks tend to be visited by nearby residents. The researchers also distributed survey forms to youths in their residential areas. The respondents were selected within the radius of 1 to 3 kilometers from the recreational parks. 
PLANNING MALAYSIA

Journal of the Malaysia Institute of Planners (2018)

\section{Analysis}

IBM SPSS Statistics version 23 was used to run the analysis. Descriptive analysis using percentage and mean was performed to present a demographic profile, the use of recreational park by Gen Z, their perceptions, as well as their needs. The descriptives were helpful in summarizing the sample.

\section{FINDINGS}

The findings discussed here are based on analyses of parameters, which include the respondents' characteristics as well as use, perception and needs of Gen Z towards recreational parks of Kuala Lumpur.

\section{Characteristic of Respondents}

Four socio-demographic parameters of the study are: area of residency, education level and occupation as shown in Figure 1.

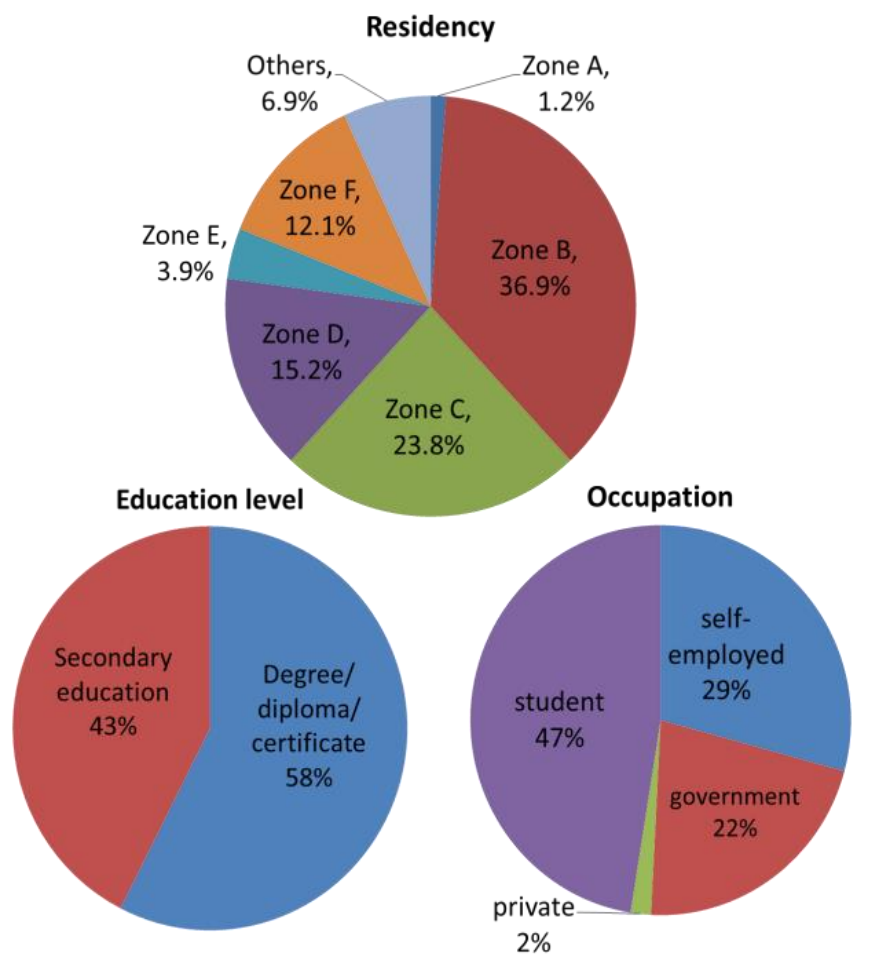

Figure 1: Characteristics of the respondents.

The Gen $\mathrm{Z}$ respondents were within the age of 15 to 21 years old $(\mathrm{n}=$ 540). Most of them live in Wangsa Maju, Maluri (Zone B) (36.9\%), followed by 
Nurfaezah Ghani, Mazlina Mansor \& Khalilah Zakariya

Gen Z's Activities and Needs for Urban Recreational Parks

Sentul, Manjalara (Zone C) (23.8\%), Damansara, Penchala (Zone D) (15.2\%), Bandar Tun Razak, Sungai Besi (Zone F) (12.1\%), Bukit Jalil, Septih (Zone E) (3.9\%) and Kuala Lumpur City Centre (Zone A) (1.2\%). 'Others' (6.9\%) represent the respondents who live in the fringe of Kuala Lumpur, such as Putrajaya, Shah Alam and Petaling Jaya. Most of the Gen $\mathrm{Z}$ were approached in well-known recreational parks, other than residential areas around the park. For examples, Titiwangsa Lake Garden in Wangsa Maju, Maluri zone and Kepong Metropolitan Park in Sentul, Manjalara zone.

Half of the respondents were degree, diploma and certificate holders $(57.5 \%)$, and another half of respondents finished their secondary education $(42.5 \%)$. The majority of respondents were students $(93.4 \%)$. The rest were either employed in the government sector $(1.2 \%)$, private sector $(3.4 \%)$ or selfemployed (2.0\%). Hence, most of the respondents are among university and high school students.

\section{Types of Recreational Parks Visited}

For this parameter, closed-ended questions in Likert scale format were analyzed. Table 1 shows the percentage on frequency of visit with format: (1) never and (2) love $($ very seldom $)=$ twice or more a year. Moderate to high scales consist of measures (3) seldom $=$ once a month, (4) sometimes $=$ twice a month, $(5)$ often $=$ once a week and (6) very often $=$ twice or more a week.

Table 1: Frequency of visit to recreational parks in Kuala Lumpur by Gen $Z$ youth.

\begin{tabular}{|c|c|c|c|c|c|c|}
\hline \multirow{2}{*}{ Park/Measure } & Never & Low & \multicolumn{4}{|c|}{ Moderate to high } \\
\hline & 1 & 2 & 3 & 4 & 5 & 6 \\
\hline \multicolumn{7}{|l|}{ City / Metropolitan Park } \\
\hline \multirow[t]{2}{*}{ a. Perdana Botanical } & \multirow[t]{2}{*}{60.1} & \multirow[t]{2}{*}{22.2} & 9.4 & 5.1 & 2.1 & 1.1 \\
\hline & & & \multicolumn{4}{|c|}{$17.7 \%$} \\
\hline \multirow[t]{2}{*}{ b. Lembah Kiara Park } & \multirow[t]{2}{*}{70.4} & \multirow[t]{2}{*}{17.7} & 6.7 & 3.2 & 0.7 & 1.2 \\
\hline & & & \multicolumn{4}{|c|}{$11.8 \%$} \\
\hline \multirow[t]{2}{*}{ c. KLCC Park } & \multirow[t]{2}{*}{22.5} & \multirow[t]{2}{*}{39.5} & 16.3 & 15.8 & 3.5 & 2.3 \\
\hline & & & \multicolumn{4}{|c|}{$37.9 \%$} \\
\hline \multicolumn{7}{|l|}{ District Park } \\
\hline \multirow[t]{2}{*}{ a. Bukit Gasing Park } & \multirow[t]{2}{*}{73.4} & 14.7 & 5.7 & 4.4 & 0.9 & 0.9 \\
\hline & & & \multicolumn{4}{|c|}{$11.9 \%$} \\
\hline \multirow[t]{2}{*}{ b. Titiwangsa Lake Garden } & \multirow[t]{2}{*}{27.5} & 32.4 & 15.8 & 14.2 & 6.2 & 3.9 \\
\hline & & & \multicolumn{4}{|c|}{$40.1 \%$} \\
\hline \multirow[t]{2}{*}{ c. Bukit Jalil Int. Park } & \multirow[t]{2}{*}{67.6} & 16.5 & 7.3 & 5.1 & 2.1 & 1.4 \\
\hline & & & \multicolumn{4}{|c|}{$15.9 \%$} \\
\hline \multirow[t]{2}{*}{ d. Permaisuri Lake Garden } & \multirow[t]{2}{*}{64.0} & 14.0 & 8.2 & 6.7 & 4.1 & 3.0 \\
\hline & & & \multicolumn{4}{|c|}{$22 \%$} \\
\hline \multirow[t]{2}{*}{ e. Kepong Metropolitan } & \multirow[t]{2}{*}{58.5} & 15.4 & 9.0 & 8.2 & 6.4 & 2.5 \\
\hline & & & \multicolumn{4}{|c|}{$26.1 \%$} \\
\hline
\end{tabular}


PLANNING MALAYSIA

Journal of the Malaysia Institute of Planners (2018)

\begin{tabular}{|c|c|c|c|c|c|c|}
\hline \multirow[t]{2}{*}{ f. Batu Metropolitan } & \multirow[t]{2}{*}{74.8} & 10.8 & 4.6 & 3.7 & 2.5 & 3.5 \\
\hline & & & \multicolumn{4}{|c|}{$14.3 \%$} \\
\hline \multirow[t]{2}{*}{ g. Danau Lumayan Park } & \multirow[t]{2}{*}{84.6} & 7.4 & 3.9 & 2.1 & 1.2 & 0.7 \\
\hline & & & \multicolumn{4}{|c|}{$7.9 \%$} \\
\hline \multirow[t]{2}{*}{ h. Pudu Ulu Lake Park } & \multirow[t]{2}{*}{84.2} & 8.5 & 2.7 & 3.4 & 0.5 & 0.7 \\
\hline & & & \multicolumn{4}{|c|}{$7.3 \%$} \\
\hline \multirow[t]{2}{*}{ i. Taman Wahyu Lake } & \multirow[t]{2}{*}{83.9} & 8.0 & 3.4 & 3.0 & 1.1 & 0.7 \\
\hline & & & \multicolumn{4}{|c|}{$8.2 \%$} \\
\hline \multirow[t]{2}{*}{ j. Alam Sutera Park } & \multirow[t]{2}{*}{84.2} & 8.7 & 2.7 & 2.7 & 1.2 & 0.5 \\
\hline & & & \multicolumn{4}{|c|}{$7.1 \%$} \\
\hline
\end{tabular}

Based on moderate to high percentage on visit, result suggests that the highest visitation is to Titiwangsa Lake Garden (40.1\%) and KLCC Park (37.9\%). Both recreational parks were well-known city parks in Kuala Lumpur. These parks were famous for their many programmes, events and activities for youth, as compared to other recreational parks in the city. They were also easily accessible because of variety of options for public transport such as LRT and buses.

Additionally, Gen Z frequently visits Kepong Metropolitan Park (26.1\%) in Sentul-Manjalara zone and Permaisuri Lake Garden (22\%) in Bandar Tun Razak-Sungai Besi zone. These recreational parks were the main neighborhood parks, surrounded by residential houses. Park users were living within 1 to $3 \mathrm{~km}$ from the main recreational parks. For Perdana Botanical Garden, despite being a city park, the park provided less space for youth activities. The park was more focused on tourist attractions, hence merely $17.7 \%$ of youths visited the park. Other parks such as Danau Lumayan Park, Pudu Ulu Lake Park and Alam Sutera Recreation Park received low percentage of visits. Gen Z was not familiar with the mentioned parks. Among the reasons that the respondents never visited the parks were transportation issues and unfamiliarity with the smaller scale parks. Limitations of the study include the bias sizes of samples from zones Wangsa Maju-Maluri (36.9\%) and Sentul-Manjalara (23.8\%).

\section{Reasons for Visiting Recreational Parks}

Figure 2 shows the mean of thirteen items on Likert scale format (1=strongly disagree; 5 strongly agree). The items relate with reasons of going to recreational parks in Kuala Lumpur. All items' mean score were greater than 3 (neutral), which indicate positive responses. 
Nurfaezah Ghani, Mazlina Mansor \& Khalilah Zakariya

Gen Z's Activities and Needs for Urban Recreational Parks

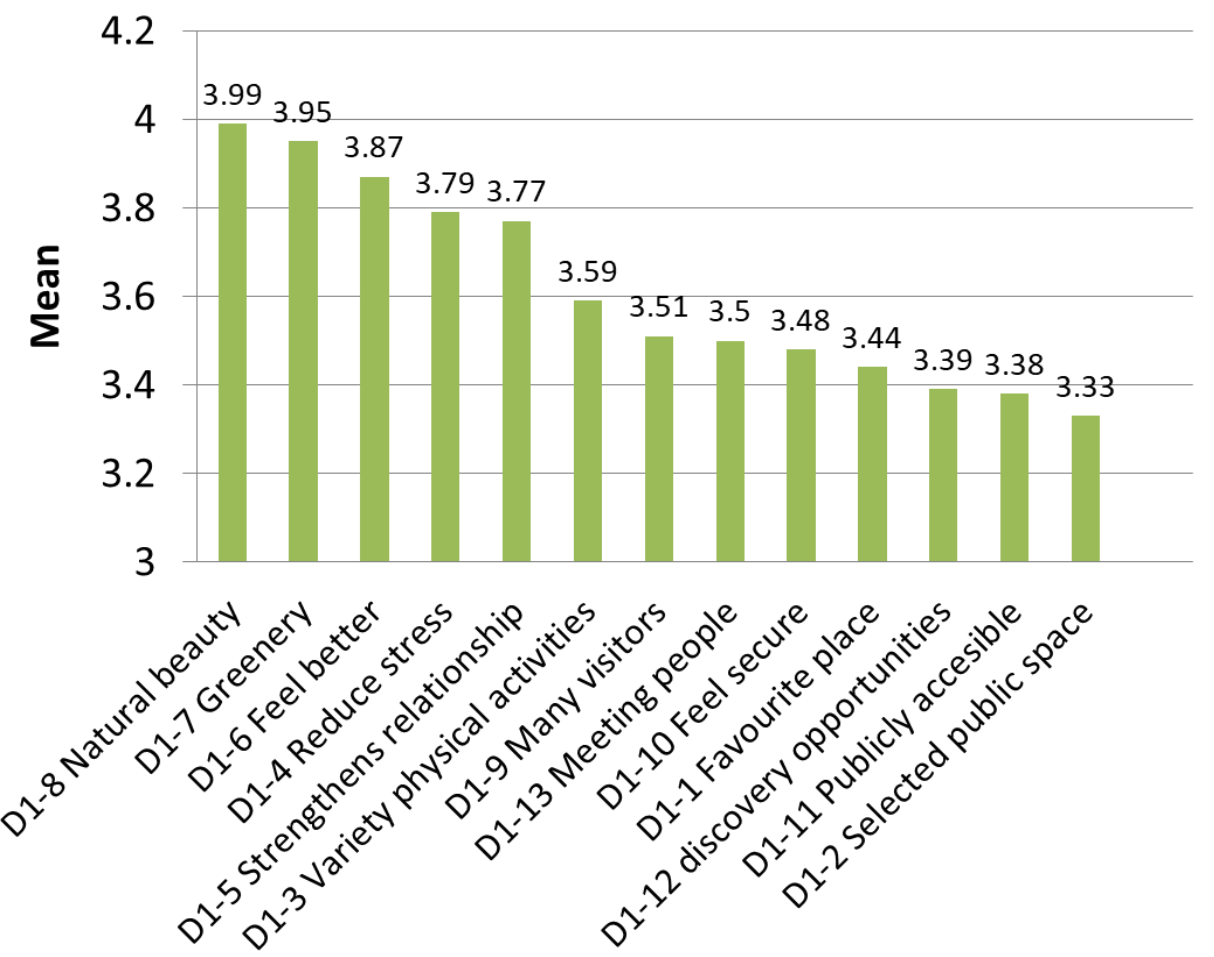

Parameter \& Measure

Figure 2: Reasons for visiting recreational park

The most agreed reasons for going to parks were: recreational parks offer nature experience (mean=3.95-3.99), provide emotional relieve (feeling better $=3.8$; relax and reduce stress $=3.79$ ), social benefits (3.77) and provision of activities (3.59). The result implied that recreational parks in Kuala Lumpur were visited due to the natural attributes, to improve emotional well-being and for socializing through various outdoor activities.

\section{Needs of Gen $Z$ in Recreational Park}

The needs of Gen $\mathrm{Z}$ of leisure time activities in recreational park were also investigated. The measures for youths' activities in recreational park were derived from the literature review obtained through international and local papers that covers from 2008 up until the current ones. Twelve measures on activities were analyzed and categorized into three parameters. They were: (a) active activities, (b) recreational activities and (c) extreme activities (Figure 3). 


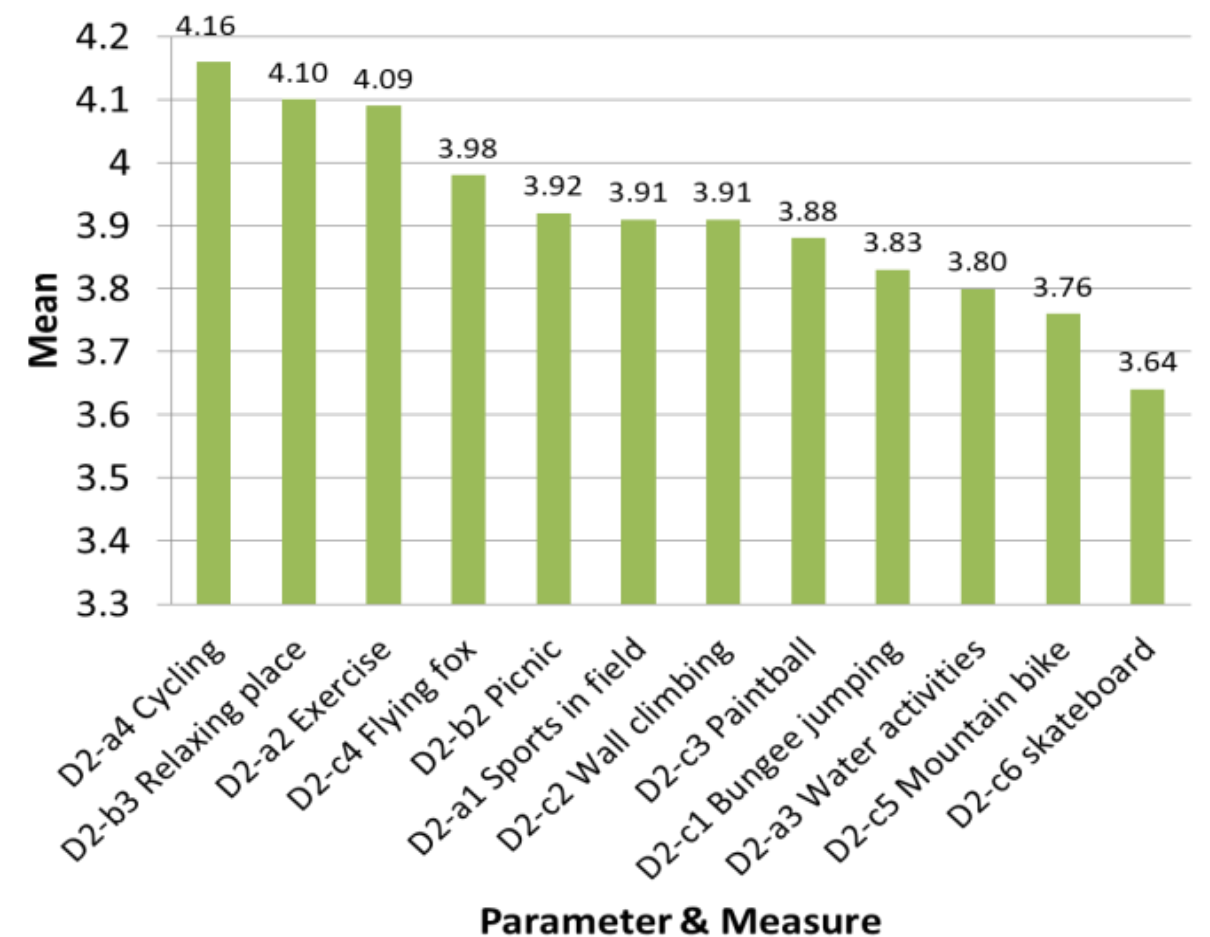

Figure 3: Needs for recreational parks (Likert scale).

Based on mean result, the majority of respondents agreed that cycling, relaxation and exercise were the top activities that they need (mean>4.00). The results showed that the function of recreational park for Gen $\mathrm{Z}$ was similar to the previous generation of youth, which was the for leisure activities that offer nature, calmness and healthy environment. Gen $\mathrm{Z}$ would like parks to offer extreme activities such as flying fox (mean=3.98), wall climbing, bungee jumping, mountain bike and skateboard $($ mean $=3.64-3.91)$. The results suggest that Gen $\mathrm{Z}$ agreed that recreational parks should offer extreme activities, which they consider necessary to attract youths. However, not all recreational parks can offer extreme activities. Extreme activities differ from active and other recreational activities, which may not be suitable for all types of recreational park. This is because it depends on the topography, functions and design intention of the parks. Even though the lifestyles of youths are changing, their primary needs of the outdoor activities still lean towards active and extreme activities, as findings and literature review suggested. Therefore, recreational parks should be up to date in design and should offer variety of activities for Gen $\mathrm{Z}$ youth to express their identity as youths. 
Nurfaezah Ghani, Mazlina Mansor \& Khalilah Zakariya

Gen Z's Activities and Needs for Urban Recreational Parks

An open-ended question was included in the questionnaire that asked about youths' needs of parks in Kuala Lumpur. The question was posed to expand to complement the closed-ended question on the item. Their answers were analysed and categorized using related keywords. 28 answers were recorded from 15 respondents. The parameters emerged were summarized and categorized into five: (i) extreme activities (39\%), (ii) traditional games (25\%), (iii) organization programs (18\%), (iv) Islamic recreation and sports (11\%) and (v) art and entertainment (7\%).

The responses revealed that currently extreme activities were increasingly in demand among Gen $\mathrm{Z}$ youth. Nonetheless, they also mentioned that traditional games in recreational park such as teng teng, galah panjang, congkak, sepak takraw, and others should also be introduced or maintained. The traditional games in a recreational park were alternative playtime activities in parks to preserve heritage and culture of people to the youth. The respondents also suggest that authorities and organizers need to offer more events or social programs in recreational parks. For examples, fitness programs (zumba, aerobic), exhibition and marathon. These events and programs acted as key attractions for some outdoor activities. Respondents also suggested that promotion on activities that were related with religious sports and recreation such as archery, horse riding and street dakwah and usrah should be conducted and could increase positive attitude among youths in their social activity. In terms of art and entertainment, the respondents prefer to have activities like busking and painting. These activities would make the recreational parks appear more exciting and invigorating for the youths.

\section{CONCLUSION}

Overall, the study found that Gen Z youth in Kuala Lumpur significantly used the recreational parks for their leisure time activities. Most of them prefer recreational park more than other public spaces because of the naturalness of the environment. The parks make them feel physically and mentally healthy. Gen Z youth also tend to spend their time in recreational park if they were near to their living area, provide favourable facilities and offer variety of events, programs and activities. The study suggests that recreational parks should also focus on design aspects for the youths such as types of activities ideal for their physical movement and recreation. Their needs of activities that are trending such as extreme sports urge improvement in provision of facilities specifically designed for youths. At the same time, their propositions on traditional games and Islamic sports suggest that the youths value heritage, culture and religious teachings. The criteria of outdoor space for youth activities meet the current needs of Gen $\mathrm{Z}$ youths. Parks should introduce spaces and activities that excite and promote positive socialization among all groups of users. 
PLANNING MALAYSIA

Journal of the Malaysia Institute of Planners (2018)

\section{ACKNOWLEDGEMENT}

This paper was supported by grant by MOHE under Grant Nos. FRGS 15-2580499.

\section{REFERENCES}

Abd-latif, R., Nor, M. M., \& Omar-Fauzee, M. S. (2011). Influence of recreational facilities among adolescents towards leisure time physical activity (LTPA). Asian Journal of Environment-Behaviour Studies, 2(5), 37-46.

Aminuddin, Y., Abdullah, M. N. H., Fauzee, M. S. O., Soh, K. G., Ismail, I. A., Abdullah, A. L., \& Adam, Y. (2009). Kajian penglibatan golongan belia dan masyarakat dalam sukan. Laporan akhir akademi Sukan, Universiti Putra Malaysia.

Biddle, S. J. H., Marshall, S. J., Gorely, T., \& Cameron, N. (2009). Temporal and environmental patterns of sedentary and active behaviors during adolescents' leisure time. International Journal of Behavioral Medicine, 16(3), 278-286.

Danis, A., Sidek, S., \& Yusof, S. M. (2014). Environmental characteristics influences on physical activity among overweight adolescents: Urban neighbourhood parks. Procedia - Social and Behavioral Sciences, 153, 402-409.

Department of Statistics Malaysia (2016). Population quick info. Retrieved March 1, 2017 , from http://pqi.stats.gov.my/result.php?token=bd7af7492d376bb6287f4523fbca8b5e

Khairuddin, S. A., Mohd Yunos, M. Y., Mydin, M. A. O, \& Ujang, N. (2015). Youth preference of extreme parks design in urban areas. Advance in Environmental Biology, 9(4), 197-200.

Lim, K. C., Mat Yusof, M., Fauzee, M. S. O., Othman, A. T., Aman, M. S., Gunathevan Elumalai, \& Mohd Ali, H. (2016). Examining sport and physical activity participation, motivations and barriers among young Malaysians. Asian Social Science, 12(1), 159-171.

Latifiyan, M., \& Salavati, M. (2015). Environment designing considering the needs of youth according to Abraham Maslow's needs case study. African Journal of Business Management, 9(1), 8-17.

Makinen, K., \& Tyrvainen L. (2008). Teenage experiences of public green spaces in suburban Helsinki. Urban Forestry and Urban Greening, 7, 277-289.

McCrindle, M., \& Wolfinger, E. (2008). The ABC of XYZ: Understanding the global generations. Sydney, Australia: University of New South Wales Press.

Ngesan, M. R., Karim, H. A., Zubir, S. S., \& Ahmad, P. (2013). Urban community perception on nighttime leisure activities in improving public park design. Procedia - Social and Behavioral Sciences, 105, 619-631.

Rabe, N. S., Osman, M. M., \& Abdullah, M. F. (2017). Assessment on public perception towards the development of 1Malaysia youth cities. Advanced Science Letters, 23(7), 6102-6105. 
Nurfaezah Ghani, Mazlina Mansor \& Khalilah Zakariya

Gen Z's Activities and Needs for Urban Recreational Parks

Poh, B. K., Safiah, M. Y., Tahir, A., Siti Haslinda, M. D., \& Siti Norazlin, N. (2010). Physical activity patterns and energy expenditure of Malaysian adults: Findings from the Malaysian adult nutrition survey. Malaysian Journal of Nutrition, 16(1), 13-37.

Rideout, V. J., Foehr, U. G., \& Roberts, D. F. (2010). Generation of M2 media in the lives of 8-18 years olds. Washington D. C.: Henry J. Kaiser Family Foundation.

Sladek, S. \& Grabinger, A. (2014). Gen Z: The first generation of the 21st Century has arrived! Retrieved May 5, 2016, from http://xyzuniversity.com/wpcontent/uploads/2014/02/GenZ_Final.pdf

Wilson, N. C. (2006). Preliminary study of the physical activity participation patterns of Malaysian youth. Kuala Lumpur: Majlis Sukan Negara Malaysia.

Zulkia, D. R., Zainol, R., Zainol, N., \& Nordin, N. A. (2014). Factors determining youth's recreational behaviour and its effects on body mass index (BMI). Journal of Surveying, Construction and Property, 5(2), 1-11. 